\title{
Medical Uses of Gold Compounds: Past, Present and Future
}

\author{
Simon P Fricker \\ Johnson Matthey Technology Centre, \\ Blount's Court, Sonning Common, \\ Reading, Berkshire, RG4 9NH, UK
}

Gold, in a variety of forms, has been used in medicine throughout the history of civilisation. In the twentieth century gold complexes were introduced for the treatment for rheumatoid arthritis, culminating in the introduction of the oral drug Auranofin in 1985. The clinical use and mechanism of action of gold drugs is reviewed here, including recent discoveries on the effect of gold drugs on gene expression. The search for new medical uses of gold is described, focusing on the anticancer and antimicrobial properties of gold compounds.

\section{MEDICAL USES OF GOLD COMPOUNDS: PAST, PRESENT AND FUTURE}

Gold has been exploited for its putative medical properties throughout the history of civilisation $(1,2)$. The earliest medical use of gold can be traced back to the Chinese in 2500 BC. In medieval Europe alchemists had numerous recipes for an elixir known as aurum potabile, many of which contained little gold! A gold cordial could be found in the new pharmacopoeias of the 17th century and was advocated by Nicholas Culpepper for the treatment of ailments caused by a decrease in the vital spirits, such as melancholy, fainting, fevers, and falling sickness. Later in the 19th century a mixture of gold chloride and sodium chloride, 'muriate of gold and soda,' $\mathrm{Na}\left[\mathrm{AuCl}_{4}\right]$ was used to treat syphilis.

The use of gold compounds in modern, twentieth century medicine began with the discovery in 1890 by the German bacteriologist Robert Koch that gold cyanide $\mathrm{K}\left[\mathrm{Au}(\mathrm{CN})_{2}\right]$ was bacteriostatic towards the tubercle bacillus. Gold therapy for tuberculosis was subsequently introduced in the 1920s. The suggestion that the tubercle bacillus was a causative agent for rheumatoid arthritis led to the use of gold therapy for this disease. Gold therapy soon proved to be ineffective for tuberculosis but, after a thirty year debate a clinical study sponsored by the Empire Rheumatism Council confirmed the effectiveness of gold compounds against rheumatoid arthritis. Since that time gold drugs have also been used to treat a variety of other rheumatic diseases including psoriatic arthritis, a form of arthritis associated with psoriasis, juvenile arthritis, palindromic rheumatism and discoid lupus erythematosus (3). Encouraging results have also been obtained with gold therapy as a treatment for various inflammatory skin disorders such as pemphigus, urticaria and psoriasis (4). Chrysotherapy, treatment with gold based drugs (from the Greek word for gold, chrysos) is now an accepted part of modern medicine.

These are the major clinical uses for gold compounds to date and there have been no major changes in this field since the introduction of auranofin for the treatment of rheumatoid arthritis in 1985. The use of antiarthritic gold compounds will therefore be discussed only briefly, and the reader is referred to the many excellent reviews on this subject (2-7). Some of the most interesting advances in the pharmacology of gold drugs have emerged from studies on their mechanism of action; and these findings, and their relationship to the biological chemistry of the gold drugs, is discussed. The future for the medicinal chemistry of gold may be in therapeutic areas other than rheumatoid arthritis and new research into the anticancer and antimicrobial activity of gold compounds will therefore be reviewed. 


\section{CHRYSOTHERAPY FOR RHEUMATOID ARTHRITIS}

Rheumatoid arthritis is an inflammatory disease characterized by a progressive erosion of the joints resulting in deformities, immobility and a great deal of pain. It is an autoimmune disease in which the body's immune system mounts a response against itself. This results in a malign growth of the synovial cells (the cells lining the joint) called a pannus, and infiltration of the joint space by cells of the immune system, primarily macrophages, and associated production of immunoglobulin proteins called rheumatoid factors. Phagocytic cells release degradative enzymes such as collagenase, and generate reactive oxygen species $\mathrm{OH}^{\circ}$ and $\mathrm{O}_{2}{ }^{-}$, all of which contribute to the resulting tissue damage. This progressive inflammatory response is promoted by raised levels of chemical mediators such as prostaglandins, leukotrienes and cytokines.

The early gold compounds used for the treatment of rheumatoid arthritis were gold(I) thiolates (AuSR) such as sodium aurothiomalate (Myocrisin ${ }^{\mathrm{TM}}$ ) (1) and aurothioglucose (Solganol ${ }^{\mathrm{TM}}$ ) (2) (Figure 1), SR being thiomalate and thioglucose respectively (3). Myocrisin $^{\mathrm{TM}}$ is still to be found in the British National Formulary for use in the treatment of arthritis. Both of these compounds are oligomers, either forming rings or chains, with a typical formula of $\left[\mathrm{Au}_{8}(\mathrm{STM})_{9}\right]$ - for Myocrisin $^{\mathrm{TM}}$, the 'extra' -SR ligand being required to cap the 'bare' gold atom at the end of the chain.

Both drugs are water soluble and have to be administered by deep intramuscular injection at weekly intervals. An initial dose of $10 \mathrm{mg}$ is given, followed by increasing doses of up to $50 \mathrm{mg}$ until the onset of remission when the dosing can be reduced (6). After rapid absorption the gold is rapidly cleared from the bloodstream and distributed to various tissues including the kidneys where it accumulates and gives rise to nephrotoxicity, a major side effect. Other adverse reactions include mouth ulcers, skin reactions, blood disorders and occasional liver toxicity (5). The gold compounds are also slow acting, requiring treatment for up to 4 to 6 months before a beneficial effect is seen.

In spite of these problems there were clear indications that gold therapy was effective in arthritis. This led to the search for a drug with an improved pharmacokinetic profile and reduced toxicity. In 1985 a new compound, auranofin, [tetra-O-acetyl-B-D(glucopyranosyl)thio](triethylphosphine)gold(I)], Ridaura $^{\text {TM }}$ (3) (Figure 1), was introduced as an orally bioavailable gold drug for arthritis (8). Auranofin is a monomeric thiolate with the general formula $\mathrm{R}_{3} \mathrm{PAuSR}$, the phosphine ligand making the compound lipophilic (5). Auranofin has several

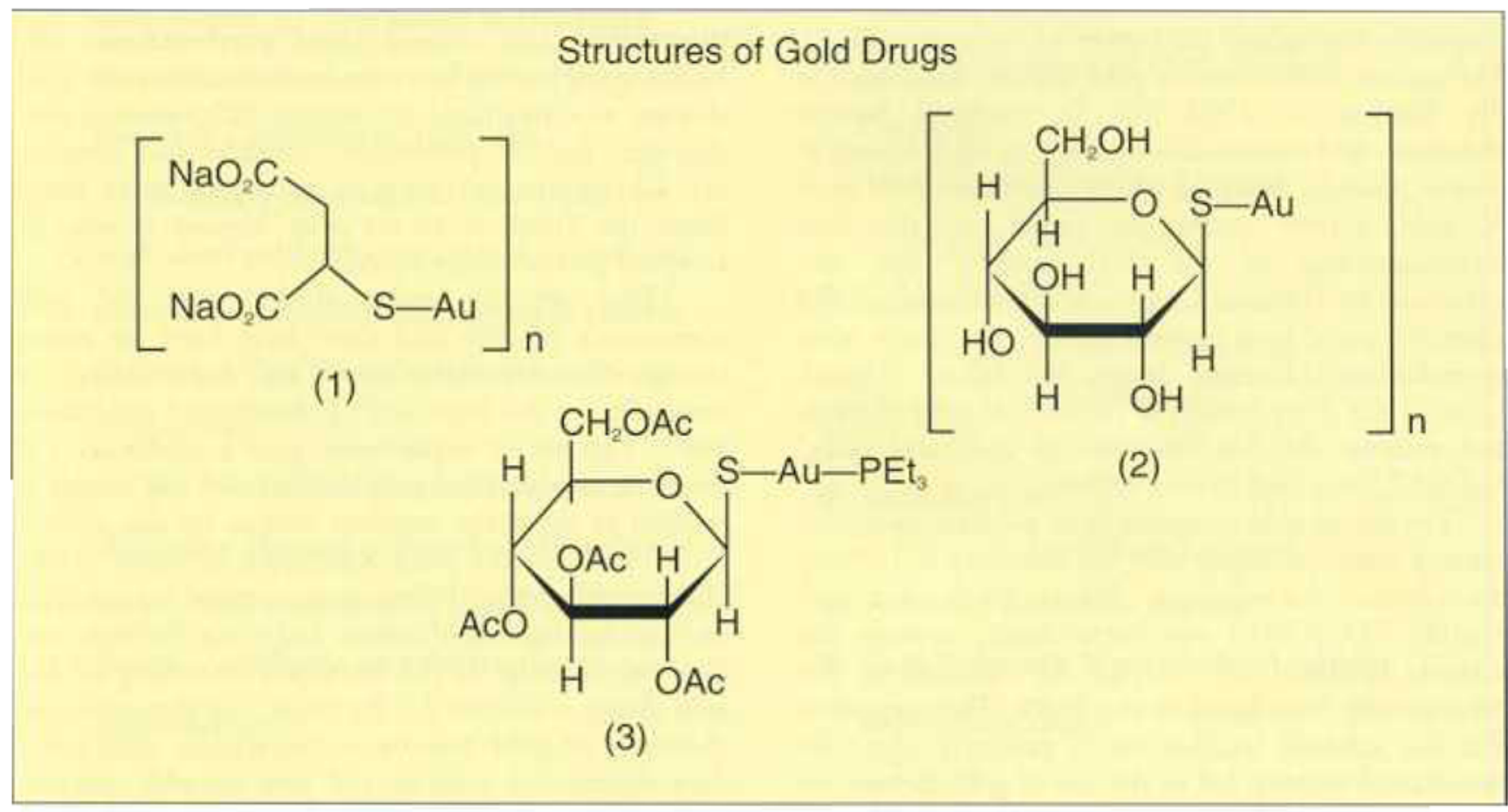

Figure 1 The structures of gold drugs for the treatment of rheumatoid arthritis; (I) sodium aurothiomalate (Myocrisin TM), (2) aurothioglucose (Solganol TMe), (3) auranofin (Ridaura TM). 
advantages over previous gold drugs, not least that it can be taken orally. Serum gold levels are reduced and maintained for longer, and there is less retention of gold in the tissues and hence renal toxicity is significantly reduced. These advantages are, however, offset by a reduction in efficacy compared with the oligomeric gold(I) thiolates.

The mechanism of action of the antiarthritic gold compounds is unclear, in part due to the lack of understanding of rheumatoid arthritis. An appreciation of the chemical interaction of gold complexes with naturally occurring ligands in a biological environment is helpful in our understanding of the pharmacological activity of the gold drugs.

\section{BIOLOGICAL CHEMISTRY OF GOLD}

There are several excellent reviews on the biological chemistry of gold (9-11) so it is appropriate to give here only a brief overview of selected aspects pertinent to the pharmacology of gold drugs. Gold can exist in a number of oxidation states: -I, 0, I, II, III, IV, and V, but only gold 0 , I, and III are stable in aqueous, and therefore, biological environments. Both gold(I) and gold(III) are unstable with respect to gold(0) and are readily reduced by mild reducing agents. Gold(I) is thermodynamically more stable than gold(III). Many gold(III) complexes are strong oxidising agents, being reduced to $A u(I)$, and this means that they are generally toxic. This reduction can be driven by biologically occurring reductants such as thiols. Gold(I) generally forms two coordinate, linear complexes such as the gold thiolate antiarthritic compounds which can undergo associative ligand exchange reactions with biological ligands. Gold(I) has a preference for 'soft' ligands and will react preferentially with S-donors rather than $\mathrm{O}$ - or $\mathrm{N}$ donors. The gold thiolate drugs will undergo ligand exchange with cysteine-rich peptides and proteins such as glutathione, metallothionein, and albumin (12), particularly where the $\mathrm{pK}_{\mathrm{a}}$ of the $\mathrm{SH}$ group is low, e.g. the cys-34 of albumin. Gold(I) can be stabilized by cyanide or thiolate ligands, including naturally occurring thiols such as the amino acid cysteine, and gold is primarily transported in the bloodstream as an albumin adduct.

There have been suggestions that auranofin has a different mechanism of action to the simple gold(I) thiolates (13). Auranofin is extensively metabolised in vitro so that the final active species is probably similar to that of the oligomeric gold complexes. There is also evidence to suggest that auranofin inhibits the production of reactive oxygen species, such as superoxide and the hydroxyl radical, produced during the oxidative burst of activated polymorphonuclear cells (a phagocytic cell of the immune system). In this case the active metabolite may be aurocyanide. One suggestion is that gold complexes may react with the cyanide released during phagocytosis forming aurocyanide. This can readily enter cells, and has been shown to inhibit the oxidative burst (3).

\section{GOLD-PROTEIN INTERACTIONS}

The ability of gold thiol compounds to undergo ligand exchange reactions with biological ligands such as the amino acid cysteine may contribute to their pharmacological activity. One proposal is that gold drugs inhibit the interaction of the degradative enzymes by reacting with thiol groups in metalloproteinases such as collagenase (7).

Gold(I) also undergoes ligand exchange with other biological proteins including albumin, and metallothioneins forming aurothioneins (12). The precise pharmacological significance of these interactions is unclear but may well provide a focus for the development of third generation antiarthritic drugs.

\section{GOLD COMPOUNDS AND GENE EXPRESSION}

Gold compounds exert a number of effects on the immune response, one of these being a reduction in cytokine levels. Recent data indicates that this may be a result of the interaction of gold with thiol groups on the proteins responsible for regulating the transcription of the genes controlling cytokine expression. Transcription is the copying of the DNA sequence encoding genes into the RNA messenger molecule. This is then subsequently translated into the protein product encoded by the gene. This process is controlled and directed by a number of ancillary proteins called transcription factors which bind to specific DNA sequences and initiate gene transcription. Regulation of gene transcription plays an important part in a number of diseases including oncogene expression in cancer and cytokine production in inflammatory disease such as rheumatoid arthritis. 
Many transcription factors contain cysteine, such as the Bzip transcription factors jun and fos oncogenes. The cysteine residues in the transcription factors encoded by the oncogenes jun and fos are flanked by the basic amino acids lysine and arginine. This results in the lowering of the $\mathrm{pK}_{2}$ of the cysteine $-\mathrm{SH}$ thus favouring ligand exchange with gold(I) thiolates. These transcription factors are known to control the transcription of a gene known as AP-1 which in turn is involved in the expression of genes for collagenase and the cytokine IL-2. It has been shown that aurothiomalate can inhibit AP-1 transcription via interaction with jun and fos (14). This has important implications for rheumatoid arthritis as another transcription factor NF- $\mathrm{BB}$, which controls transcription of other inflammatory mediators including Tumour Necrosis Factor (TNF), also contains a cysteine flanked by lysine and arginine. It is therefore possible that one molecular mechanism for the gold antiarthritic drugs is inhibition of transcription of crucial mediators of the inflammatory process.

\section{ANTICANCER ACTIVITY OF GOLD COMPOUNDS}

The discovery of the antitumour activity of cisplatin, cis-[ $\left.\mathrm{PtCl}_{2}\left(\mathrm{NH}_{3}\right)_{2}\right]$, in 1969 prompted the search for other metal-containing antitumour drugs $(15,16)$. Gold has been included in this search; and there has been intensive effort to identify a gold antitumour drug. There were early indications that auranofin had limited antitumour activity in in vitro systems and in the P388 leukaemia in vivo, however, it was inactive against solid tumours. Several other gold(I) phosphines with thiosugar ligands were investigated with similar results.

More promising indications were achieved with a series of digold phosphine complexes. The lead compound was $\left[\mathrm{dppe}(\mathrm{AuCl})_{2}\right]$ (4) (Figure 2). The dppe ligand itself exhibits antitumour activity, and it has been suggested that the gold serves to protect the ligand from oxidation and aids in the delivery of the active species. This is an oversimplification, however, and there is substantial evidence to support a direct role for the gold in the anticancer activity of this complex (15). The digold phosphine complex was shown to rearrange to give the tetrahedral complex $\left[\mathrm{Au}(\mathrm{dppe})_{2}\right]+$ (5) (Figure 2) (17). The tetrahedral complex is more stable as the chelate effect stabilises the compound, and the phosphine ligand is more inert

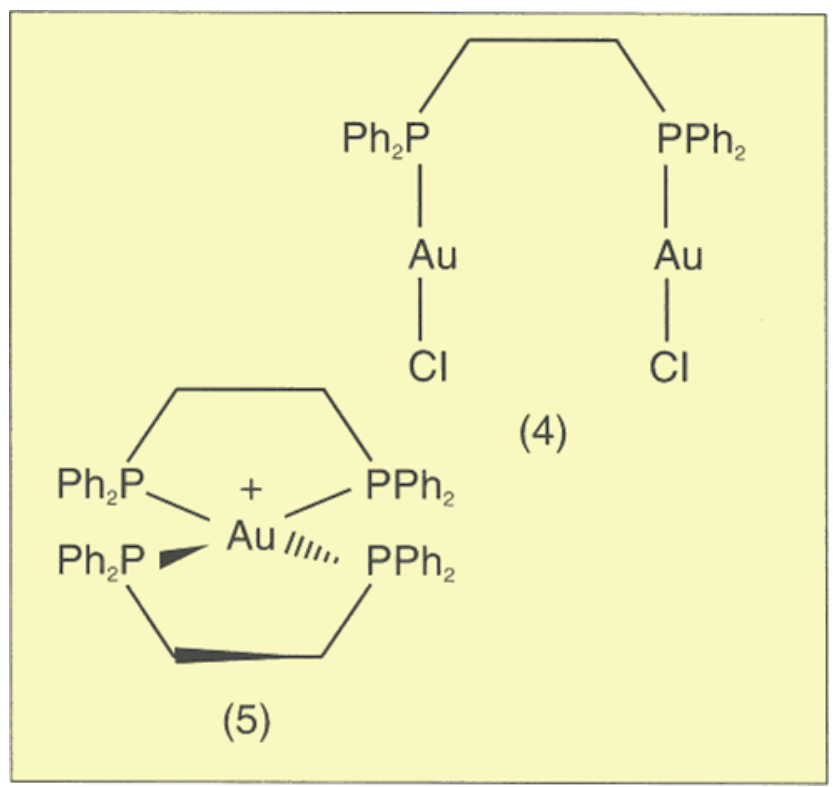

Figure 2 The structures of anticancer gold(I) phosphine compounds; (4) $\left[d p p e(A u C l)_{2}\right]$, (5) $\left[A u(d p p e)_{2}\right]^{+}$.

to substitution by the types of thiolate ligands that could be encountered in a biological environment. The proposed mechanism of action for $\left[\mathrm{Au}(\mathrm{dppe})_{2}\right] \mathrm{Cl}$ was the formation of DNA-protein crosslinks, the lack of affinity for $\mathrm{Au}(\mathrm{I})$ for $\mathrm{O}$ - and $\mathrm{N}$ - containing ligands resulting in poor reactivity with the bases of DNA (18). Though this compound had marked activity against peritoneal cancer cells, $\left[\mathrm{Au}(\mathrm{dppe})_{2}\right] \mathrm{Cl}$ was still only slightly active against solid tumour models. This compound was not entered for clinical trials, however, due to problems with cardiotoxicity highlighted during pre-clinical toxicology studies (19).

One avenue of investigation has been to synthesize gold complexes containing ligands with known antitumour activity (16). Examples of this are a series of $\mathrm{Ph}_{3} \mathrm{PAu}(\mathrm{I})$-nucleotide complexes containing ligands such as 5-fluorouracil and 6-mercaptopurine; phosphinogold(I) ferrocene complexes such as $[\mu-1,1-$ bisbis(diphenylphosphino)ferrocene] bis(chlorogold(I)), and more recently a series of novel nitrogen containing phosphinogold(I) ferrocenes (20); and a gold(III) complex of streptonigrin, a substituted 7amino-quinoline-5,8,-dione (16).

Gold(III) complexes have not been as thoroughly investigated as gold(I) complexes, primarily because of their reactivity. Gold(III) is isoelectronic $\left(\mathrm{d}^{8}\right)$ with platinum(II) and likewise forms square planar complexes. It is therefore tempting to speculate that such complexes would have similar antitumour activity to cisplatin. One approach has been to synthesize 
complexes with a single mononegative bidentate ligand, damp, (2-[(dimethylamino)methyl]phenyl), and two monodentate anionic ligands e.g. $\mathrm{Cl}$ or acetate $(\mathrm{OAc})$ (Figure 3 ). The damp ligand forms part of a five-membered chelate ring in which the nitrogen

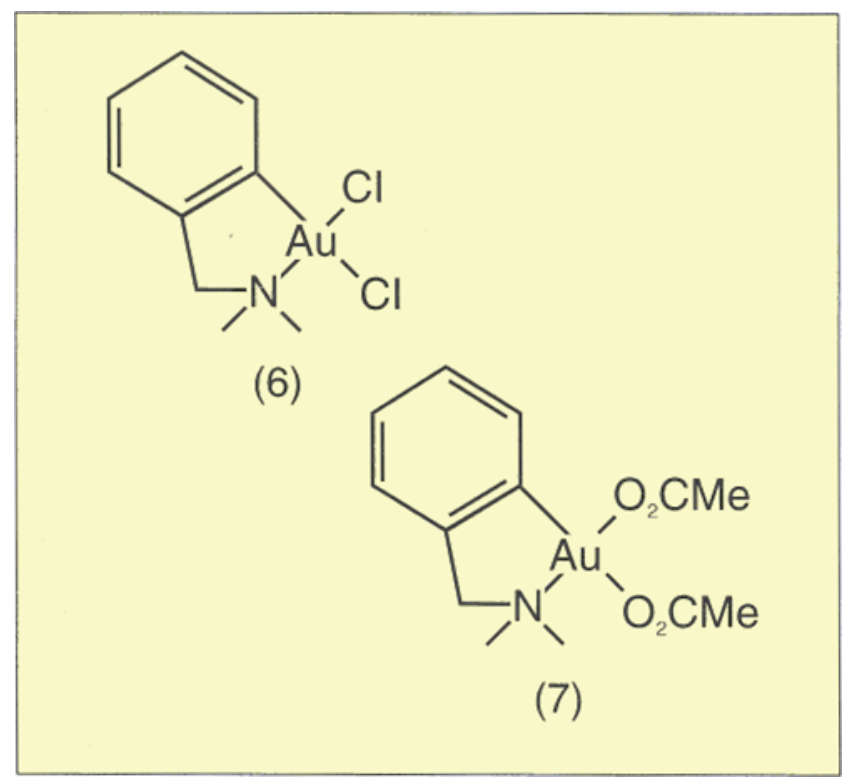

Figure 3 The structures of gold(III) compounds with antitumour and antibacterial activity in experimental models; (6) $\left[\mathrm{AuCl}_{2}(\right.$ damp)], (7) $\left[\mathrm{Au}(\mathrm{OAc})_{2}(\mathrm{damp})\right]$.

of the amine group and the carbon of the aryl ring bond to the metal. The monodentate ligands are readily hydrolysed and are available for substitution.

These gold(III) complexes have been evaluated against an in vitro panel of human tumour cell lines comprising cells of different tissue types and different responses to cisplatin (21). Differential toxicity, as opposed to non-selective toxicity, across the cell line panel is used as an indicator of potential antitumour activity (22). Most of the cell lines used in this panel can also be grown as solid tumour xenografts in immune-deprived, nude, mice and this means the compounds can be further evaluated in an in vivo setting. Initial in vitro studies indicated that the breast carcinoma cell line ZR-75-1 was sensitive to $\left[\mathrm{AuCl}_{2}(\mathrm{damp})\right]$ (6) (Table 1). This compound was then further tested in vivo against a xenograft of the same tumour cells where it demonstrated modest antitumour activity, seen as a reduction in tumour growth compared with controls, and comparable to cisplatin activity against the same tumour in vivo (Figure 4). Further analogues of $\left[\mathrm{AuCl}_{2}\right.$ (damp)] have been evaluated in this way (21). Biochemical studies

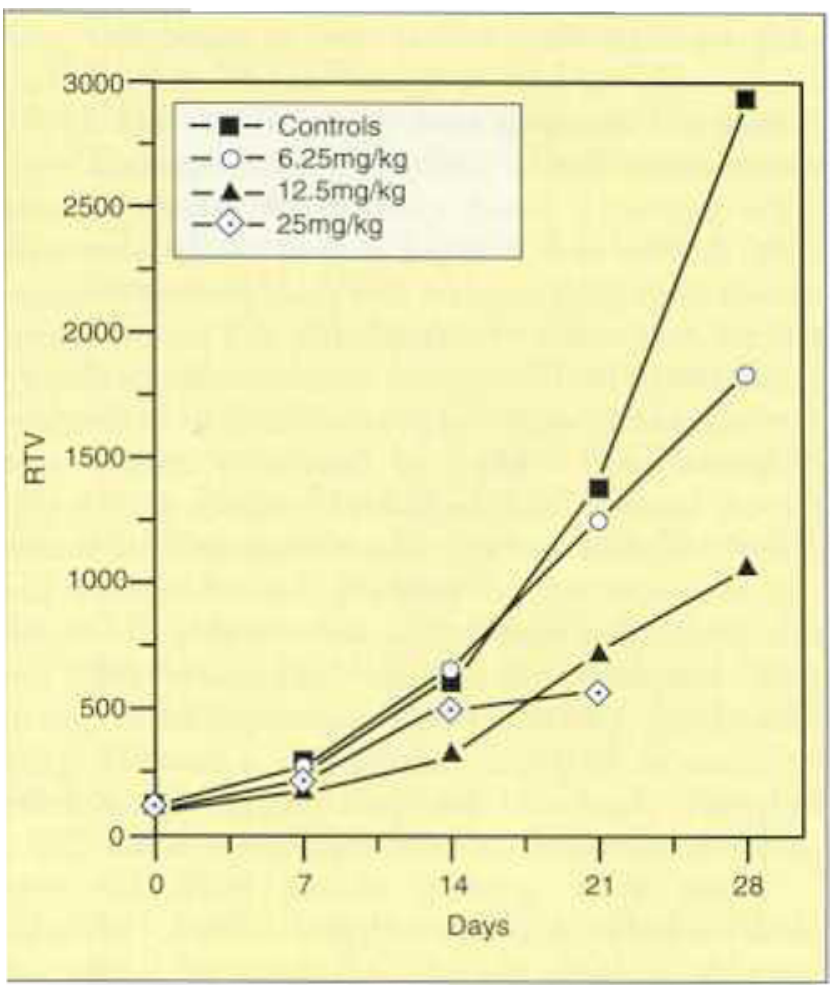

Figure 4 The effect of $\left[\mathrm{AuCl}_{3}(\right.$ damp $\left.)\right]$ on the growish of the ZR-75-1 breast tumour xenograft. The componnd was administered on days 0,7,14 and 21. Timour grows th is expressed as relative tumour volume, RTV. $R T V=100 \times$ (mean volume of tumour at assessment (ime) $/$ (mean tumour nolume ar start).

$$
I C_{50}(\mu \mathrm{g} / \mathrm{ml})
$$

$\begin{array}{lccccccc}\text { SW620 } & \begin{array}{c}\text { SWIII6 } \\ \text { (colon) }\end{array} & \begin{array}{c}\text { SW403 } \\ \text { (colon) }\end{array} & \begin{array}{c}\text { ZR-75-1 } \\ \text { (breast) }\end{array} & \begin{array}{c}\mathrm{HT} 29 / 219 \\ \text { (rectum) }\end{array} & \begin{array}{c}\mathrm{HTI} 376 \\ \text { (bladder) }\end{array} & \begin{array}{c}\text { SK-OV-3 } \\ \text { (ovary) }\end{array} \\ {\left[\mathrm{AuCl}_{2}(\mathrm{damp})\right]} & 50 & 48 & 56 & 11 & 22 & 12 & 18 \\ {\left[\mathrm{PtCl}_{2}\left(\mathrm{NH}_{3}\right)_{2}\right]} & 120 & 135 & 200 & 15 & 30 & 15 & 14\end{array}$

Table 1 Cytotoxicity of gold (III) complex against a panel of human tumour cell lines. Cisplatin is included for comparison. The $I C_{50}$ is the concentration of compound giving $50 \%$ inhibition of cell growth. 
(23) indicate that these compounds have a mechanism of action significantly different to that of cisplatin suggesting that this is a potentially important novel class of metal-containing antitumour agents.

\section{ANTIMICROBIAL ACTIVITY OF GOLD COMPOUNDS}

The implication of microbial infection as a causative agent in arthritis was the stimulus for the investigation of the antimicrobial properties of gold complexes. The early work by Robert Koch demonstrated that gold compounds were active against the tubercle bacillus. Subsequent extensive work in the 1930's and 1940's demonstrated that a variety of gold compounds were active against a broad spectrum of microorganisms (24). Activity in in vitro test systems was demonstrated against both gram negative and gram positive bacteria, a number of strains of mycoplasma, and the protozoan Leishmania. Gold complexes were also able to modify the course of a number of in vivo infections in a variety of animal hosts. Many of these early studies were flawed, however, and the lack of evidence for the role of an infectious agent in rheumatoid arthritis meant that this work was not pursued. Since then there has been little novel work on the antimicrobial activity of gold complexes. There are indications that the antiarthritic gold complexes may suppress $H$ pylori infections in the gastric mucosa (25), a causative agent for peptic ulcers, and that gold phosphine complexes in vitro are cytocidal towards Pseudomonas putida (26).

There is a growing clinical need for new antimicrobial agents. The therapeutic efficacy of drugs currently available for the treatment of a class of bacteria known as the 'problem Gram positive cocci' is limited by the emergence of multiply-resistant strains such as methicillin-resistant Staphylococus aureus
(MRSA) and enterococci e.g. Enterococcus faecalis (27). Vancomycin is the drug of choice for these organisms but it too has limitations as it must be administered by intravenous infusion, and has problems with resistance, particularly against the enterococci.

In recent studies a number of different metal complexes have been tested for antimicrobial activity (28). The compounds were tested against a number of bacterial strains including clinical isolates of methicillin-resistant $S$. aureus (MRSA), methicillinsensitive $S$. aureus, enterococci, coagulase-negative staphylococci, and streptococci. A gold(I) thiocyanate complex $\left[\mathrm{Au}(\mathrm{SCN})\left(\mathrm{PMe}_{3}\right)\right]$ demonstrated activity against Gram positive bacteria including MRSA. Comparative toxicity against mammalian cells was estimated in vitro against the $\mathrm{CHO}$ rodent cell line. The complex $\left[\mathrm{Au}(\mathrm{SCN})\left(\mathrm{PMe}_{3}\right)\right]$ demonstrated good selectivity for bacteria over mammalian cells with an $\mathrm{MIC}_{50}$, minimum concentration inhibiting $50 \%$ bacterial growth, of 0.33 against Staphylococcus aureus and 0.77 against Enterococcus faecalis, and with toxicity against the $\mathrm{CHO}$ cells at concentrations at least $10 \mathrm{x}$ greater than the MIC. This compound was also active in an in vivo murine model of topical, skin surface, infection achieving a 2-3 log reduction for all test organisms, including Staphylococcus aureus and Enterococcus faecalis, compared with controls (29).

Further investigation of gold complexes has led to the identification of a series of gold(I) phosphonium dithiocarboxylate complexes which also have activity against Gram positive bacteria, including the 'problem Gram positive cocci' (28). The antimicrobial activity of the gold(III) compounds $\left[\mathrm{AuCl}_{2}\right.$ (damp)] (6) and $\left[\mathrm{Au}(\mathrm{OAc})_{2}(\right.$ damp) $](7)$ (Figure 3 ) has been investigated (29). Both exhibit broad spectrum activity against a range of organisms, with a small degree of specificity against the Gram positive organisms $S$. aureus and $E$.

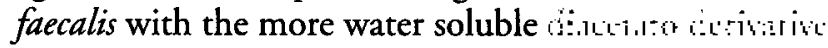

$\operatorname{MIC}(\mu g / \mathrm{ml})$

$\begin{array}{lcccc} & \text { S. aureus } & \text { E. faecalis } & \text { E. coli } & \text { P. aeruginosa } \\ {\left[\mathrm{AuCl}_{2}(\mathrm{damp})\right]} & 1.0-2.5 & 1.0-2.5 & 10-25 & 10-25 \\ {\left[\mathrm{Au}(\mathrm{OAc})_{2} \text { (damp) }\right]} & 0.25-1.0 & 0.25-1.0 & 2.5-10 & 50-100\end{array}$

Table 2 Antibacterial activity of gold(III) complexes against a range of bacteria. $M I C$ is the range between the highest concentration allowing growth and the lowest inbibiting growth. 
being the most potent (Table 2). Both are similarly toxic against the mammalian $\mathrm{CHO}$ cells indicating that the diacetato complex is the more selective of the two complexes for bacteria over mammalian cells.

\section{CONCLUSIONS}

Gold therapy has been a component of the physicians stock in trade since the earliest days of civilisation. In the twentieth century chrysotherapy has become established as an important part of the treatment regimen for rheumatoid arthritis. In terms of drug discovery no major advances have been made for the last decade, despite the considerable effort to find new therapeutic uses for gold compounds, particularly for anticancer therapy. However, our understanding of the mechanism of these drugs continues to improve, particularly with the exciting observations of the effect of gold drugs on gene expression. After sixty years of chrysotherapy it is possible that an improved understanding of the molecular and biochemical mechanism of gold compounds will provide the impetus for new advances in the medical use of gold drugs.

\section{ABOUT THE AUTHOR}

Dr Simon Fricker is a Principal Scientist in the Biomedical Technology Department at the Johnson Matthey Technology Centre, where he has been responsible for pharmacology and toxicology for 12 years, on the research and development of novel inorganic pharmaceuticals.

\section{REFERENCES}

G.J. Higby, Gold Bull., 1982, 15, 130

R.V. Parish, Interdisc. Sci. Rev., 1992, 17, 221

3 G.D. Champion, G.G. Graham and J.B. Ziegler, Balliéré's Clin. Rheumatol.,1990, 4, 491

4 R.E. Thomas and R.A. Papandrea, Med. J. Aust., $1993,158,720$

R.V. Parish and S.M. Cottrill, Gold Bull., 1987, 20, 3

6 N.L. Gottlieb, J. Rheumatol., 1982, 9 (Suppl. 8), 99

7 R.M. Snyder, C.K. Mirabelli and S.T. Crooke, Semin. Arthritis Rheum.,1987, 17, 71

8 T.G. Davis (ed), Scand. J. Rheumatol., Supplement 63, 1986

$9 \quad$ P.J. Sadler, Struct. Bonding, 1976, 29, 171
10 C.F. Shaw III, Inorg. Persp.' Biol. Med., 1979, 2, 278

1 D.H. Brown and W.E. Smith, Chem. Soc. Rev., 1980, 9, 217

12 C.F. Shaw III, Comments Inorg. Chem., 1989, 8, 233

13 D.T. Walz, M.J. Dimartino and D.E. Griswold, J. Rheumatol, 1982, 9, Suppl. 8, 54

14 M.L. Handel, C.K.W. Watts, A. deFazio, R.O. Day and R.L. Sutherland, Proc. Natl. Acad. Sci. USA, 1995, 92, 4497

15 O.M. Ni Dhubhghaill and P.J. Sadler, in 'Metal Complexes in Cancer Chemotherapy', ed. B.K. Keppler, VCH, Weinheim, 1993, p. 221.

16 C.F. Shaw III, in 'Metal Compounds in Cancer 'Therapy', ed. S.P. Fricker, Chapman and Hall, London, 1994, p. 46

17 C.K. Mirabelli, R.K. Johnson, S.T. Crooke, M.R. Mattern, S.M. Mong, C.M. Sung, G. Rush, S.J. Berners-Price, P.S. Jarrett and P.J. Sadler, in '5th International Symposium on Platinum and Other Metal Coordination Compounds in Cancer Chemotherapy', ed. M. Nicolini and G. Bandoli, Cleup, Padua, Italy, 1987, p. 319

18 S.J. Berners-Price, P.S. Jarrett and P.J. Sadler, Inorg. Chem., 1987, 26, 3074

19 G.D. Hoke, R.A. Macia, P.C. Meunier, P.J. Bugelski, C.K. Mirabelli, G.F. Rush and W.D. Matthews, Toxicol. Appl. Pharmacol., 1989, 100, 293

20 M. Viotte, B. Gautheron, M.M. Kubicki, I.E. Nifant'ev and S.P. Fricker, Metal Based Drugs, 1995, 2, 311

21 R.V. Parish, B.P. Howe, J.P. Wright, J. Mack, R.G. Pritchard, R.G. Buckley, A.M. Elsome and S.P. Fricker, Inorg. Chem., 1996, 35, 1659

22 S.P. Fricker, in 'Metal Ions in Biology and Medicine', ed. Ph. Collery, L.A. Poirier, M. Manfait and J-C. Etienne John Libby Eurotext, Paris, 1990, p. 452

23 A.M. Elsome, $\mathrm{PhD}$ Thesis, King's College, London, 1995

24 J.H. Liebarth and R.H. Persellin, Agents and Actions, 1981, 11, 458

25 L. Girgis, P.G. Conaghan and P. Brooks, Curr.Opin. Rheumatol., 1994, 6, 252

26 M.D. Rhodes, P.J. Sadler, M.D. Scawen and S. Silver, J. Inorg. Biochem., 1992, 46, 129

27 W. Brumfitt, J.M.T. Hamilton-Miller, Drugs Exptl. Clin. Res., 1990, 16, 205

28 A.M. Elsome, W. Brumfitt, J.M.T. HamiltonMiller, P.D. Savage, R.O. King and S.P. Fricker, 
in 'Program and Abstracts of the 31st Interscience Conference on Anti-Microbial Agents and Chemotherapy, Chicago', American Society for Microbiology, Washington, DC, 1991, Abstract 387, p. 163

29 A.M. Elsome, J.M T. Hamilton-Miller, W.
Brumfitt and W.C. Noble, J. Antimucrob. Chemother, 1996, 37, 911

30 R.V. Parish, J. Mack, L. Hargreaves, J.P. Wright, R.G. Buckley, A.M. Elsome, S.P. Fricker and B.R.C. Theobald, J. Chem. Soc., Dalton Trans., 1996, 69

\section{Studies on Activation Mechanism for $\mathrm{Au} / \mathrm{Zn}$ CO-Sensing Systems}

A recent paper describes the use of Fourier Transform Infrared Spectroscopy (FTIR) and quadruple mass spectroscopy to assist in understanding the processes of adsorption and oxidation of $\mathrm{CO}$ on an $\mathrm{Au} / \mathrm{ZnO}$ sample (1). ${ }^{16} \mathrm{O}_{2}$ and ${ }^{18} \mathrm{O}_{2}$ were used to demonstrate that $\mathrm{CO}$ adsorbed on gold sites at the perimeter interface with $\mathrm{ZnO}$ reacts with surface lattice oxygens to form carbonate-like intermediates. It is claimed that this reaction and the decomposition of the intermediates is the principal reason for the conductivity changes in the semiconducting metal oxide when in contact with $\mathrm{CO}$ in air.

The oxygen adsorbed from the air onto gold vicinal sites facilitates nucleophilic attack by surface oxygen on the CO. It had been previously shown that highly dispersed gold appreciably enhances the sensitivity and selectivity to $\mathrm{CO}$ detection (2). The samples for the recent study were prepared by co-precipitation from $\mathrm{HAuCl}_{4}$ and $\mathrm{Zn}\left(\mathrm{NO}_{3}\right)_{2}$ solutions, followed by calcination in air at $400^{\circ} \mathrm{C}$. TEM micrographs showed that the gold particles were homogeneously dispersed on $\mathrm{ZnO}$, with particle diameters smaller than $5 \mathrm{~nm}(1,3)$. The infrared spectra were run at room temperature in an infrared cell designed to examine samples in situ, under controlled atmospheres.

\section{The results showed that:}

- $\mathrm{CO}$ is activated by gold in three molecular forms: a linear carbonyl species bonded at Au terrace, step and kink sites, a carbonyl species bonded to Au borderline sites, and a carbonyl species also interacting with $\mathrm{Zn}$ cations, via the $\pi$-orbitals.
- The high CO oxidation activity of Group 11 (IB) elements supported on $\mathrm{ZnO}$ can be related to the high basicity of oxygen atoms adsorbed on these metals and/or to a perturbation of the oxide defect equilibria by metal/oxide junction effects.

- Two independent pathways are possible for $\mathrm{CO}$ oxidation on the $\mathrm{Au} / \mathrm{ZnO}$ sample, i.e. molecular oxygen reacts directly with $\mathrm{CO}$ at the surface of the gold particles, leading to the formation of molecular $\mathrm{CO}_{2}$, or molecular oxygen activates or enhances the reactivity of $\mathrm{CO}$ species adsorbed at the border of gold particles with the surface oxygens.

- The electron-withdrawing effect of the adsorbed oxygen facilitates the nucleophilic attack of surface oxygens on the CO.

The chemistry described in this paper could be used as a basis for catalytic gas sensor systems designed for the detection of carbon monoxide.

\section{David Thompson}

\section{References}

1 F. Boccuzzi, A. Chiorino, S. Tsubota and M. Haruta, Sensors and Actuators, 1995, B24-25, 540

2 T. Kobayashi, M. Haruta, H. Sano and M. Nakane, Sensors and Actuators, 1988, 13, 339

3 M. Haruta, N. Yamada, T. Kobayashi and S. Iijima, J. Catal., 1989, 115, 301 